\title{
Gender and Conditional Support for Torture in the War on Terror
}

\author{
Donald P. Haider-Markel
}

\section{University of Kansas}

\section{Andrea Vieux}

\section{University of Kansas}

The events of September 11 have clearly changed the way that Americans think about politics and policy and may have changed attitudes about the treatment of America's perceived enemies. At the same time, revelations about American interrogation techniques in the war on terror have forced a national dialogue on human rights during a time of war. Americans do tend to oppose a variety of harsh interrogation techniques, but opposition appears to be conditioned by gender, partisanship, and the context in which an interrogation might take place. We explore how conditions shape attitudes on interrogation techniques in the war on terror, with a particular focus on gender and contextual framing. We analyze data from a unique 2004 national survey of American adults to test several hypotheses. Our results suggest that gender strongly shapes opposition to harsh interrogation techniques, but contextual framing also shapes opposition. Partisanship and contextual framing also mediate the influence of gender on attitudes.

The terrorist attacks of September 11 have clearly changed the way that
Americans think about politics and policy and may have generated

The authors thank the Program on International Policy Attitudes (PIPA) at the University of Maryland for making the data used in this analysis publicly available. A previous version of this manuscript was presented as part of a research symposium at the University of Nebraska, March 2007. We thank Mark Joslyn, Kevin Smith, and John Fulwider for their comments on earlier drafts of this manuscript.

Published by Cambridge University Press 1743-923X/08 \$15.00 for The Women and Politics Research Section of the American Political Science Association.

(C) 2008 The Women and Politics Research Section of the American Political Science Association. DOI: $10.1017 / \mathrm{S} 1743923 \mathrm{X} 08000019$ 
support for the use of extreme techniques, even torture, in obtaining information about potential terrorist attacks. Likewise, revelations about harsh interrogation techniques by American government agents in the Iraqi Abu Ghraib prison, secret Central Intelligence Agency (CIA) detention centers, and the Guantanamo Bay prison have shocked most observers and forced Americans to evaluate their beliefs concerning human rights during a time of war (Greer 2004; Hooks and Mosher 2005; Kull 2006; McCoy 2006). In addition, experts continue to question the value of information obtained through the use of physical or emotional distress. ${ }^{1}$

Although partisan differences in support of counterterrorism measures are clear in survey after survey since 2002 (Davis and Silver 2004; Huddy et al. 2002; Huddy et al. 2005; Jacobson 2007), we know far less about the other factors that shape attitudes about counterterrorism policies. Given the importance of civil liberties and human rights in the war on terror, understanding the forces that shape opinion on counterterrorism policies is imperative. As policymakers continue to debate the use of military force, warrantless surveillance, and interrogation techniques that most observers define as torture, understanding public preferences and the factors that shape those preferences should motivate social science research.

We suggest that an important focus of this research should be on the role of gender and contextual frames in determining attitudes. Research consistently finds gendered responses to the use of violence and punitive measures. Public attitudes about the treatment of the accused, whether the charges concern a terrorist conspiracy or dealing drugs, are strongly shaped by gender, with women tending to be less supportive of harsh treatment or severe sentencing (Hurwitz and Smithey 1998; Warr 1995). Meanwhile, attitudes about terrorism and government response are influenced by the manner in which the issue is framed - attitudes change depending on how the issue is presented (Haider-Markel, Joslyn, and Al-Baghal 2006; Iyengar 1989).

Although no previous studies have systematically examined gender differences on opposition to torture, attitude differences between women and men on issues of punitive punishment for crime, and fear of crime, as well as support for violent foreign policy actions such as military engagement, have been reported (Bjereld 2001; Haghighi and Lopez 1998; Hurwitz and Smithey 1998; Kaufmann and Petrocik 1999; 
Ortega and Myles 1987; Smith 1984; Warr 1995; Wilcox, Hewitt, and Allsop 1996).

Thus, through our research we seek to understand whether opposition attitudes about interrogation techniques are influenced by gender and also the context in which the interrogation of suspected terrorists is framed. The first section will outline the theoretical reasons we might expect gender and contextual differences in support of extreme interrogation techniques. Next, we analyze responses to a unique 2004 poll by the Program on International Policy Attitudes (PIPA), which asked a random sample of American adults about their opinions on the use of different interrogation techniques that might be used to elicit information about terrorist organizations and possible terrorist attacks. Our findings suggest that support for various interrogation techniques is strongly predicted by gender and context, with women and respondents who are exposed to contextual scenarios where information is less likely to prevent a terrorist attack being more inclined to oppose harsh techniques. In addition, contextual frames and partisanship mediate the effects of gender on attitudes. We conclude with a discussion of the implications of our findings and offer directions for future research.

\section{UNDERSTANDING ATTITUDES ABOUT TORTURE: GENDER AND CONTEXT}

Although there is no generally agreed upon definition of the behaviors and actions in the course of interrogation that constitute torture, one legal observer may have put it best when he argued that defining torture means "picking out a point along a continuum at which the observer's queasiness turns to revulsion" (Posner 2004, 291). Although some individuals will define certain interrogation techniques as torture, and therefore unacceptable, others might not view that same technique as torture, and therefore acceptable. In trying to define torture, we can see that defining some interrogation techniques as torture, while others are not, implies that observers would support those techniques they do not view as torture, but oppose those they do define as torture. In other words, attitudes on this issue are conditioned by the specifics of the situation. Indeed, national polls conducted by the Pew Research Center since 2004 reveal that some Americans would support torture under some conditions. Pew asked "Do you think the use of torture against 
suspected terrorists in order to gain important information can often be justified, sometimes be justified, rarely be justified, or never be justified?" In 2007, about $12 \%$ of Americans indicated that torture often could be justified, while only $29 \%$ indicated that torture could never be justified. However, for the majority of respondents, $56 \%$, torture could be justified in some conditions (31\% indicating sometimes and 25\% indicating rarely) (The Pew Research Center 2007).

Because a majority of Americans clearly would support torture under at least some conditions, we expect support also to be conditioned by the interrogation techniques used, including those that range from relatively benign tactics to harsh measures that could cause mental or physical discomfort and pain. In addition, the point at which any observer might be made uneasy, and therefore unsupportive, by an interrogation technique is likely dependent on individual characteristics, such as experience with pain, discomfort, feeling threatened or fearful, or perhaps a willingness to accept violence. However, research on punitive measures for criminal wrongdoing suggests that those who have experienced crime or been threatened are not more likely to support punitive measures for criminals (Unnever, Cullen, and Fisher 2007). Likewise, those who are more fearful of being a victim of terrorism are not more supportive of harsher counterterrorism measures (Huddy et al. 2005).

Meanwhile, some individual characteristics are undoubtedly related to support for violence and punitive measures against wrongdoing. For example, women are consistently more likely to oppose violence in the media, violent punishment for wrongdoing, and the violence of war as represented by casualties (Conover and Sapiro 1993; Hurwitz and Smithey 1998; Shapiro and Mahajan 1986; Smith 1984; Unnever, Cullen, and Fisher 2007; Warr 1995). Likewise, although women are more anxious about being a victim of terrorism, women were also less likely to support a variety of counterterrorism policies, including military actions following the 9/11 attacks (Huddy et al. 2005).

So why are women more likely to oppose violence and punitive measures for wrongdoers, and why would women be more likely to oppose torture? In what has come to be known as a "social constructionist" perspective, Carol Gilligan (1982) has argued that females are socialized differently than males, in that females are taught to believe that strength derives from seeing connections with others and providing empathy and care for others (see also McCue and Gopoian 2000). Males meanwhile are socialized to believe that strength comes from being independent, 
forceful, and competitive (Brody 1990; Gilligan 1982; Hurwitz and Smithey 1998; Stanko 1990). Gilligan (1983) and Alissa Pollitz Worden (1993) argue that these different socialization processes lead women to develop an "ethic of care," whereby females tend to see "society as an interdependent and interconnected web of personal relationships; from this perspective moral or just behavior entails actively attempting to nurture and protect others and the relationships among them" (Worden 1993, 206). Indeed, in terms of the use of military force, women are more likely to be concerned about humanitarian issues and the loss of life (Eichenberg 2003).

Men, on the other hand, develop an "ethic of justice," which tends to focus on self-determination, absolute truth, and safety through physical strength (Gilligan 1982, 166; Stanko 1990, 110). Research on the attitudes of young children lends support to the socialization argument. Ulf Bjereld's (2001) analysis of six- to nine-year-old children found no significant difference between the foreign policy attitudes of males and females on armed resistance and self-defense, among other foreign policy issues, while adults who were asked the same questions exhibited significant gender differences.

In addition, early socialization differences between males and females are reinforced in adulthood as men and women face "different genderbased socially structured opportunities," such as who is expected to work outside the home, raise children, care for parents, and behave within organizations, such as corporations (Hooyman and Gonyea 1995, 22-23; see also McCue and Gopoian 2000). At a minimum, socialization patterns appear to increase men's approval of the use of force and violence to solve problems, whereas women are encouraged to view force and violence as a last resort for solving problems or resolving conflicts (Conover and Sapiro 1993; Smith 1984), and these early socialization processes may be reinforced through the life span (Hooyman and Gonyea 1995; McCue and Gopoian 2000).

The socialization of gender differences may not simply encourage women to be empathetic and men to prefer violence. Instead, the socialization process may, in fact, be more akin to social learning. Bjereld (2001) argues that the lack of gender differences in children's foreign policy attitudes is consistent with a power relations perspective. From this perspective:

the differences in opinion between men and women are grounded in the unequal power relations, which create different gender-based interests in 
issues concerning violence and use of violence. Generally, women have fewer political and social resources than men, and women would simply have more to lose from assigning legitimacy to violence.... [F] rom a power relations perspective, it is obvious that men's bigger physical strength is a disadvantage for women (Bjereld 2001, 314).

But even if the process is one of women learning that supporting violence may put them at a disadvantage ${ }^{2}$ versus learning empathy or the value of interconnected relationships, gender differences in attitudes are still the result of socialization in this perspective.

Gender differences in attitudes about torture may emerge from other socialization processes as well - women may be socialized to be more fearful of threats and this fear may shape their attitudes. As Leonie Huddy et al. (2002) and Huddy et al. (2005) noted, women are far more likely than men to overestimate the risk of being victimized by crime and terrorism, are more fearful of crime, and are more likely to exhibit anxiety about a variety of security issues (see also Fischhoff et al. 2003; Lerner et al. 2003). This high level of anxiety among women may contribute to gender differences in attitudes about counterterrorism measures, including the use of harsh interrogation techniques to obtain information, in that women might be more supportive of torture. However, higher anxiety among women does not fully explain gender differences in attitudes about counterterrorism policy since research demonstrates that anxiety and gender are both significant predictors of attitudes on counterterrorism measures (Davis and Silver 2004; HaiderMarkel, Joslyn, and Al-Baghal 2006; Huddy et al. 2002; Huddy et al. 2005). Thus, gendered differences in anxiety about terrorist threats cannot explain gender differences in attitudes on torture.

From what has come to be known as an "essentialist" perspective, biology may also contribute to gender differences in attitudes (Nincic and Nincic 2002). For example, in several experiments, a team of neurobiologists examined stated attitudes and neural processes in the brain that are associated with revenge and empathy. Their survey results of participants suggested that men stated a stronger desire for revenge against unfair play in a game than did women, and that men's attitudes were associated with increased activity in regions of the brain associated with emotions, whereas women's attitudes were not associated with

2. Nincic and Nincic (2002) would likely classify this perspective as a "consequentialist" perspective in which individual attitudes are shaped by perceived consequences of those attitudes. Here, women might be less supportive of military force or violence because they view themselves as likely victims. We include this perspective under the broader rubric of socialization or social learning. 
similar neural spikes in activity (Singer et al. 2006). Likewise, men's propensity to support violence may stem from higher levels of testosterone and other biological differences related to roles in child nurturing (Nincic and Nincic 2002).

Thus, given the socialization and biological arguments concerning the attitudes of women and men toward violence, we should expect the average woman to be less supportive of interrogation techniques that imply or involve violence. Men, meanwhile, should on average be less averse to techniques that are perceived as violent. For those techniques that do not imply or involve violence, we do not expect a significant gender difference in attitudes.

What of those techniques that do not imply or involve violence but instead are intended to sexually violate or humiliate detainees? For example, well-documented episodes at the Iraqi Abu Ghraib prison involved forcing detainees to go naked or otherwise be humiliated (Hooks and Mosher 2005). Would women view these techniques as equivalent to violence, and therefore unacceptable? We believe so primarily because women are more aware of the threat of sexual violence, including rape, than are men (Hurwitz and Smithey 1998). Indeed, much of the difference between men and women in terms of fear of crime can be attributed to a fear of rape (Huddy et al. 2002). As such, we expect that women will be less supportive than men of interrogation techniques that involve sexual violation or humiliation.

Finally, if gender is an important predictor of attitudes on the use of torture, is the effect conditional? Susan Howell and Christine Day (2000) find that the effects of gender on political attitudes is conditioned, or mediated, by such factors as education, religion, and having children. In models accounting for these types of demographic characteristics, the effect of gender on attitudes is often reduced, sometimes to statistical insignificance. At the same time, women who have more education, for example, are more likely than men or less educated women to support feminism. Meanwhile, women with children are more likely to support social welfare spending. Thus, in our attempts to model attitudes on torture, we should also explore potential interactions between gender and other characteristics. We can ask: Although women might be less supportive of harsh interrogation techniques while Republicans are more supportive, what of Republican women? Does gender make a difference once we account for partisanship?

Likewise, Richard Eichenberg (2003) finds that gender differences on the use of military force are conditioned by the nature of the use of force 
and the goals of the operation - gender differences decreased when the goals were humanitarian, but increased when questions made reference to causalities. The conditional effects found by Eichenberg suggest that gender differences on the use of force, and potentially violence generally, might be conditioned by the manner in which the issue is framed. Issue framing refers to specific presentations of issues or conditions that focus on one dimension of an issue over others. A focus on one dimension of an issue makes this dimension more accessible to the receiver and, thus, may lead the receiver to hold a different attitude than he or she would have otherwise (Haider-Markel, Joslyn, and AlBaghal 2006; Iyengar 1989, 1990). In the case of torture, and our expectations that women will be less supportive, can one ask whether there are ways in which the issue can be framed that would make women more likely to support harsher interrogation techniques of suspected terrorists, such as an increased likelihood that information collected from a suspected terrorist could prevent a terrorist attack and perhaps save lives? We suspect so. Thus, our analysis of the unique data described in the following sections allows us to examine the potential effects of issues frames, or the context of interrogation, on gendered support for torture.

\section{DATA AND VARIABLES}

Our data are from a national-random sample telephone survey of adults conducted by the Program on International Policy Attitudes/ Knowledge Networks from July 9 to 15,2004 . Respondents were asked a variety of questions related to national leaders, the war on terrorism, interrogation techniques, Sudan, and demographic characteristics. Surveys were completed with 892 adults, and the survey margin of error is $\pm 3.3 \%$. $^{3}$

Respondents were asked whether or not they would favor a series of interrogation techniques that could be used against suspected terrorists in an attempt to gain information. (The questions are listed in the Appendix.) Techniques employed ranged from offering a positive incentive to holding a detainee's head under water to applying electric shocks. Although majorities of adults favored more benign techniques, such as forcing a detainee to go without sleep or maintaining a

3. More details on the survey methodology and questionnaire can be found on the PIPA Website under the terrorism link at: www.pipa.org/archives/us_opinion.php (December 13, 2007). 
physically stressful condition, at least 35\% of respondents opposed any technique other than providing a positive incentive, and at least $15 \%$ of respondents supported the use of any technique. Responses to the questions on the use of 15 techniques serve as the dependent variables for our analysis, with Favor/Support coded as one and Oppose coded as zero.

Our key predictor variable is gender. To capture gender, we code respondents as one for female and zero for male. Our first step in analyzing gender differences in attitudes was to estimate simple crosstabulations. (The descriptive statistics are displayed in the Appendix.) For comparison purposes, we also display differences in attitudes of Republicans and Democrats. Across all of the questions, except question 14 in which positive incentives are offered, the gender and partisan differences in attitudes are statistically significant (Pearson chi-square test, $\mathrm{p}<.05)$. Simply viewing the percentage of respondents approving and disapproving of various techniques allows one to see clear gender differences, often more than 10 percentage points, as well as large partisan differences.

In addition, we made use of previous research that examines attitudes toward criminal justice, violence, and war to identify individual characteristics that should be controlled for in our models. As the chisquare tests in the Appendix make clear, one important characteristic is likely to be partisanship. Although some Democrats lean to the ideological right, and some Republicans lean to the ideological left, on average Republicans tend to be more conservative and more likely to hold far-right political attitudes (Huckfeldt et al. 1999). Ira Rohter (1969) examined the characteristics of those on the radical right and argued that rightism is associated with an extrapunitive nature. Since Republicans are more likely to hold far-right views, in Rohter's (1969) terms, Republicans should hold the most punitive attitudes toward those labeled as terrorists and be more likely to support harsh interrogation techniques against suspected terrorists. We measure partisanship by separating Republicans and Democrats and use independents as a reference group. Thus, respondents are coded one for Republican and zero for all other categories, and one for Democrat and zero for all other categories. ${ }^{4}$

4. Republicans are those identifying strongly or leaning toward the Republican Party. Democrats are those identifying strongly or leaning toward the Democratic Party. Use of the full five-point scale as a variable in our models, rather than the dichotomous measures we created, provides similar substantive results. However, the overall fit of the models declines. As such, we opted for the improved fit offered by the dichotomized measures of partisanship. 
Because individuals with more education are less likely to support punitive punishment for crime and engagement in violent activity (Barkan and Cohn 2005; Bjereld 2001; Cullen, Fisher, and Applegate 2000; Wilcox, Hewitt, and Allsop 1996), we expect that more educated respondents will be less supportive of most interrogation techniques and include a nine-point scale capturing educational attainment. And although anxiety, feeling threatened, and fear of terrorism might indirectly shape attitudes about counterterrorism, including torture (Davis and Silver 2004; Huddy et al. 2002; Huddy et al. 2005), the survey does not contain any direct measures of anxiety. ${ }^{5}$ We indirectly measure potential anxiety with variables for having children under the age of 18 and living in an urban area. Residents of urban areas and those with younger children might be more anxious than others about a terrorist attack, and therefore be more likely to support harsh interrogation techniques.

We also include measures of age (simple year count), race (whiteCaucasian coded one), martial status (never married coded one), and region of residence (South coded one), but have no expectations concerning the influence of these characteristics on attitudes.

\section{FRAMING THE CONTEXT}

One unique feature of the PIPA survey was an experimental design that allowed us to examine the potential effect of framing the context of an interrogation; each respondent was randomly exposed to one of four hypothetical contexts. About one-quarter of the total sample was assigned to each experimental condition. The sections of each context that differ are marked in italics and bold, but the

5. The closest alternative measure of threat in the survey was the following question: "Currently there is a debate about whether, when it comes to interrogating detainees who are suspected of involvement in terrorism or who might have information that would be useful in the war on terrorism, the US should be able to make exceptions to the legal prohibitions on the treatment of detainees. Here are some arguments. Please select whether you find them convincing or unconvincing: Given what we learned from the September 11 attacks, we cannot afford to tie our hands by declaring off limits any method for getting information that could be useful in the war on terrorism." Responses: Convincing (52\%), Unconvincing (44\%), No answer (4\%). One might expect that respondents who felt most threatened by terrorism would be the most likely to find this argument convincing. Clearly only about half of respondents were convinced, and a simple cross-tab reveals that women and men did not significantly differ on this question (probability $=.730$ ). Without a gender difference, we were not convinced that the question accurately measures threat. Furthermore, the performance of gender in predicting attitudes on the use of techniques does not substantively change if we include this question as an independent variable in the models. 
interviewers did not emphasize these sections. The scenarios were read as follows:

SCENARIO 1. "Let's say that the US is holding someone prisoner and intelligence sources say that there is a modest chance that this prisoner has some information about a suspected member of a terrorist group, but the prisoner denies having such information. Please select whether you would favor or oppose using each of the following methods as a way of trying to get the prisoner to reveal the information he may have."

SCENARIO 2. "... modest chance that this person has some information about a possible terrorist attack on the US that may prove critical to stopping the attack..."

SCENARIO 3. "... strong chance that this person has some information about a suspected member of a terrorist group ..."

SCENARIO 4. "... strong chance that this person has information about a possible terrorist attack on the US that may prove critical to stopping the attack ..."

Note that the first and third scenarios focus on obtaining information about a terrorist group, while the second and fourth scenarios focus on obtaining information to prevent a terrorist attack against the United States. In addition, the first and second scenarios suggest there is a modest chance that a prisoner has information, while the third and fourth scenarios indicate there is a strong chance that a prisoner has information. As such, scenarios two and four provide the most ominous situation - preventing a terrorist attack - while scenarios three and four more strongly indicate that a prisoner has important information. The scenarios should function in a manner similar to experimental issue frames, where respondent opinion is shaped by the manner in which an issue is presented (Haider-Markel, Joslyn, and Al-Baghal 2006; Iyengar 1989, 1990). Here, we expect the context in which an interrogation is presented to shape respondent attitudes. Thus, we expect that relative to exposure to Scenario 4, respondents exposed to the other three scenarios will be somewhat less likely to favor harsh interrogation techniques. Following this logic, our models include dichotomous variables for Scenarios 1, 2, and 3, and use Scenario 4 as a baseline. Each dichotomous variable (for Scenarios 1, 2, and 3) should decrease the likelihood of supporting harsh interrogation techniques. 


\section{RESULTS AND DISCUSSION}

Because responses to the questions on interrogation techniques are dichotomous, favor or oppose, we employ logistic regression analysis. ${ }^{6}$ Following the estimation of each logistic model, marginal effect coefficients were estimated. The marginal effect coefficients allow one to directly compare the relative effect of each variable in the model. Put simply, larger coefficients indicate a greater relative influence in predicting the likelihood of favoring a specific interrogation technique. The results are displayed in Tables 1 to 3.

A look across the 15 models reveals several important findings. First, few of the control variables consistently predict support for interrogation techniques. Living in the South is not significantly associated with attitudes on torture. Respondents who have never been married were less likely to support depriving detainees of sleep or bombarding them with noise. Living in an urban area increases the likelihood of supporting techniques in at least two cases, and having young children decreases support in at least one case. Meanwhile, whites were somewhat more likely to oppose only two techniques, hitting or kicking and forcing a detainee to maintain a stressful position. Overall, the control variables are inconsistent predictors of attitudes toward interrogation techniques.

Older respondents were somewhat more likely to oppose several interrogation techniques, including withholding food or water, punching or kicking, and threatening with dogs. Likewise, more educated respondents were more likely to oppose hooding detainees, punching or kicking, and electric shock. Educated respondents were also more likely to support the use of positive incentives.

Meanwhile, the results indicate that partisanship is a strong predictor of attitudes. As expected, relative to Independents and Democrats, Republicans were more likely to support all harsh techniques, except

6. As an alternative to estimating models to predict responses to each of the 15 questions, we explored methods for combining the questions into one dependent variable. Simply summing the responses (with reverse coding on positive incentives) and estimating a regression equation provides results that are substantively the same as those presented, with the key independent variables, gender and context, statistically significant at less than .01 . We also combined the questions using unrotated principal-component factor analysis. This yielded one factor explaining over $50 \%$ of the variance across 13 of the 15 questions, an Eigenvalue of 5.89, a Scale reliability coefficient of .8988, and each variable loading on the factor at .61 or higher (questions 14 and 15 were less strongly correlated with one factor and were dropped). A regression equation with the factor score as the dependent variable also provides similar substantive results, with the key independent variables, gender and context, statistically significant at less than .01 . 
Table 1. Predicting support for interrogation tactics, Part 1

\begin{tabular}{|c|c|c|c|c|c|}
\hline $\begin{array}{l}\text { Independent } \\
\text { Variables }\end{array}$ & Deprive Sleep & Hood on Head & $\begin{array}{l}\text { Bombard with } \\
\text { Noise }\end{array}$ & $\begin{array}{c}\text { Threaten to } \\
\text { Shoot }\end{array}$ & $\begin{array}{c}\text { Expose to Extreme } \\
\text { Heat or Cold }\end{array}$ \\
\hline Republican & $\begin{array}{l}.237^{* * *} \\
(.042)\end{array}$ & $\begin{array}{l}.175^{*} \text { 凂 } \\
(.046)\end{array}$ & 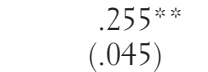 & $\begin{array}{l}.137^{\text {等 }} \\
(.046)\end{array}$ & $\begin{array}{l}.178^{* * *} \\
(.045)\end{array}$ \\
\hline Democrat & $\begin{array}{c}-.021 \\
(.044)\end{array}$ & $\begin{array}{c}-.062 \\
(.046)\end{array}$ & $\begin{array}{c}-.017 \\
(.047)\end{array}$ & $\begin{array}{c}-.052 \\
(.044)\end{array}$ & $\begin{array}{r}-.089^{*} \\
(.041)\end{array}$ \\
\hline Female & $\begin{array}{r}-.084^{*} \\
(.039)\end{array}$ & $\begin{array}{r}-.080 * \\
(.040)\end{array}$ & $\begin{array}{c}-.141^{\text {*3. }} \\
(.039)\end{array}$ & $\begin{array}{c}-.128^{* * * *} \\
(.036)\end{array}$ & $\begin{array}{c}-.102 \% \text { * } \\
(.035)\end{array}$ \\
\hline Education & $\begin{array}{l}.003 \\
(.019)\end{array}$ & $\begin{array}{l}.043^{*} \\
(.020)\end{array}$ & $\begin{array}{l}.017 \\
(.020)\end{array}$ & $\begin{array}{r}-.020 \\
(.018)\end{array}$ & $\begin{array}{c}-.012 \\
(.017)\end{array}$ \\
\hline Age & $\begin{array}{c}-.002 \\
(.001)\end{array}$ & $\begin{array}{c}-.003 \# \\
(.001)\end{array}$ & $\begin{array}{c}-.002 \# \\
(.001)\end{array}$ & $\begin{array}{r}-.000 \\
(.001)\end{array}$ & $\begin{array}{c}-.002 \# \\
(.001)\end{array}$ \\
\hline White & $\begin{array}{l}.058 \\
(.050)\end{array}$ & $\begin{array}{l}.071 \\
(.050)\end{array}$ & $\begin{array}{r}-.006 \\
(.051)\end{array}$ & $\begin{array}{c}-.073 \\
(.050)\end{array}$ & $\begin{array}{r}-.072 \\
(.049)\end{array}$ \\
\hline Never married & $\begin{array}{c}-.123^{*} \\
(.057)\end{array}$ & $\begin{array}{r}-.086 \\
(.057)\end{array}$ & $\begin{array}{c}-.139 \% \\
(.055)\end{array}$ & $\begin{array}{l}.030 \\
(.053)\end{array}$ & $\begin{array}{r}-.014 \\
(.048)\end{array}$ \\
\hline Children $<18$ & $\begin{array}{r}-.036 \\
(.050)\end{array}$ & $\begin{array}{r}-.018 \\
(.050)\end{array}$ & $\begin{array}{r}-.043 \\
(.050)\end{array}$ & $\begin{array}{c}-.019 \\
(.045)\end{array}$ & $\begin{array}{l}.020 \\
(.043)\end{array}$ \\
\hline South & $\begin{array}{l}.042 \\
(.039)\end{array}$ & $\begin{array}{l}.051 \\
(.040)\end{array}$ & $\begin{array}{l}.053 \\
(.041)\end{array}$ & $\begin{array}{r}-.056 \\
(.037)\end{array}$ & $\begin{array}{l}.016 \\
(.035)\end{array}$ \\
\hline Place size $>$ urban & $\begin{array}{l}.100 \% \\
(.050)\end{array}$ & $\begin{array}{l}.089 \\
.050)\end{array}$ & $\begin{array}{l}.038 \\
(.050)\end{array}$ & $\begin{array}{l}.040 \\
(.045)\end{array}$ & $\begin{array}{l}.070 \# \\
(.040)\end{array}$ \\
\hline Scenario 1 & $\begin{array}{c}-.168^{* * * *} \\
(.053)\end{array}$ & $\begin{array}{r}-.135 \% \\
(.052)\end{array}$ & $\begin{array}{c}-.168^{* * * *} \\
(.051)\end{array}$ & $\begin{array}{c}-.123^{* * * *} \\
(.043)\end{array}$ & $\begin{array}{c}-.079 \# \\
(.041)\end{array}$ \\
\hline Scenario 2 & $\begin{array}{c}-.148 * \\
(.055)\end{array}$ & $\begin{array}{c}-.097 \# \\
(.054)\end{array}$ & $\begin{array}{c}-.113^{*} \\
(.053)\end{array}$ & $\begin{array}{c}-.068 \\
(.046)\end{array}$ & $\begin{array}{r}-.056 \\
(.043)\end{array}$ \\
\hline Scenario 3 & $\begin{array}{c}-.121^{*} \\
(.057)\end{array}$ & $\begin{array}{r}-.070 \\
(.055)\end{array}$ & $\begin{array}{c}-.095 \# \\
(.054)\end{array}$ & $\begin{array}{c}-.057 \\
(.047)\end{array}$ & $\begin{array}{r}-.062 \\
(.043)\end{array}$ \\
\hline
\end{tabular}


Table 1. Continued

\begin{tabular}{|c|c|c|c|c|c|}
\hline $\begin{array}{l}\text { Independent } \\
\text { Variables }\end{array}$ & Deprive Sleep & Hood on Head & $\begin{array}{l}\text { Bombard with } \\
\text { Noise }\end{array}$ & $\begin{array}{c}\text { Threaten to } \\
\text { Shoot }\end{array}$ & $\begin{array}{c}\text { Expose to Extreme } \\
\text { Heat or Cold }\end{array}$ \\
\hline Constant & $\begin{array}{l}.697 \\
(.531)\end{array}$ & $\begin{array}{c}-.039 \\
(.522)\end{array}$ & $\begin{array}{c}.550 \\
(.525)\end{array}$ & $\begin{array}{l}.226 \\
(.551)\end{array}$ & $\begin{array}{l}.043 \\
(.589)\end{array}$ \\
\hline Log likelihood & -475.522 & -494.351 & -492.917 & -465.095 & -426.066 \\
\hline Pseudo R-square & .07 & .06 & .07 & .05 & .07 \\
\hline Chi square & 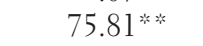 & $66.47^{\text {* * * }}$ & 77.39 皮 & 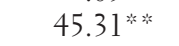 & 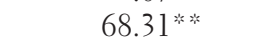 \\
\hline $\mathrm{N}$ & 763 & 762 & 767 & 762 & 766 \\
\hline
\end{tabular}

Notes: Coefficients are marginal effects coefficients computed following logistic regression estimation; standard errors are in parentheses. ${ }^{* *} \mathrm{p}<.01,{ }^{*} \mathrm{p}<.05$, \#p $<$ .10. The data are from a random-sample national telephone survey of adults conducted for the Program on International Policy Attitudes, "Americans on Detention, Torture, and the War on Terrorism," July 9 to 15, 2004. 
Table 2. Predicting support for interrogation tactics, Part 2

\begin{tabular}{|c|c|c|c|c|c|}
\hline Independent Variables & Withhold Food/Water & Punch or Kick & Force Naked & Hold Head Under Water & Threaten to Harm Family \\
\hline \multirow[t]{2}{*}{ Republican } & $.165^{* * *}$ & $.062 *$ & $.106^{* * *}$ & $.062 *$ & $.108 *$ \\
\hline & $(.047)$ & $(.031)$ & $(.039)$ & $(.031)$ & $(.041)$ \\
\hline \multirow[t]{2}{*}{ Democrat } & -.033 & $-.056^{*}$ & $-.098^{2}$ & -.041 & -.048 \\
\hline & $(.045)$ & $(.028)$ & $(.036)$ & $(.028)$ & $(.038)$ \\
\hline \multirow[t]{2}{*}{ Female } & -.023 & $-.059 \%$ & $-.137^{*}$ & 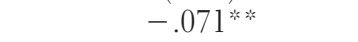 & $-.096^{* * 2 *}$ \\
\hline & $(.037)$ & $(.025)$ & $(.031)$ & $(.024)$ & $(.031)$ \\
\hline \multirow[t]{2}{*}{ Education } & -.002 & $-.026^{*}$ & .023 & -.016 & -.000 \\
\hline & $(.018)$ & $(.012)$ & $(.016)$ & $(.012)$ & $(.016)$ \\
\hline \multirow[t]{2}{*}{ Age } & $-.003^{*}$ & $-.002 *$ & -.001 & -.001 & -.001 \\
\hline & $(.001)$ & $(.001)$ & $(.001)$ & $(.001)$ & $(.001)$ \\
\hline \multirow[t]{2}{*}{ White } & .066 & $-.081^{*}$ & -.034 & -.044 & -.057 \\
\hline & $(.050)$ & $(.039)$ & $(.044)$ & $(.035)$ & $(.045)$ \\
\hline \multirow[t]{2}{*}{ Never married } & -.032 & .004 & -.063 & .046 & .039 \\
\hline & $(.051)$ & $(.033)$ & $(.039)$ & $(.038)$ & $(.047)$ \\
\hline \multirow[t]{2}{*}{ Children $<18$} & -.043 & -.023 & -.041 & .007 & -.004 \\
\hline & $(.044)$ & $(.026)$ & $(.036)$ & $(.027)$ & $(.038)$ \\
\hline \multirow[t]{2}{*}{ South } & .042 & -.010 & .007 & .002 & -.025 \\
\hline & $(.038)$ & $(.024)$ & $(.032)$ & $(.023)$ & $(.031)$ \\
\hline \multirow[t]{2}{*}{ Place size $>$ urban } & .057 & .043 & .035 & .033 & .021 \\
\hline & $(.045)$ & $(.027)$ & $(.037)$ & $(.026)$ & $(.038)$ \\
\hline \multirow[t]{2}{*}{ Scenario 1} & $-.142 \%$ & -.060 & -.048 & $-.054^{*}$ & $-.120 \%$ \\
\hline & $(.043)$ & $(.025)$ & $(.038)$ & $(.024)$ & $(.033)$ \\
\hline \multirow[t]{2}{*}{ Scenario 2} & $-.124^{*}$ & $-.063^{*}$ & -.010 & $-.061^{*}$ & $-.100^{* * * x^{*}}$ \\
\hline & $(.044)$ & $(.024)$ & $(.040)$ & $(.023)$ & $(.033)$ \\
\hline \multirow[t]{2}{*}{ Scenario 3} & $-.100^{*}$ & $-.069 \%$ & -.045 & $-.063^{*}$ & $-.093^{*}$ \\
\hline & $(.045)$ & $(.024)$ & $(.039)$ & $(.023)$ & $(.034)$ \\
\hline Constant & .463 & .601 & -.629 & .281 & -.230 \\
\hline
\end{tabular}


Table 2. Continued

\begin{tabular}{|c|c|c|c|c|c|}
\hline Independent Variables & Withhold Food/Water & Punch or Kick & Force Naked & Hold Head Under Water & Threaten to Harm Family \\
\hline & $(.542)$ & $(.754)$ & $(.621)$ & $(.772)$ & $(.616)$ \\
\hline Log likelihood & -472.652 & -289.894 & -395.279 & -278.342 & -390.915 \\
\hline Pseudo R-square & .05 & .07 & .08 & .08 & .06 \\
\hline Chi square & $45.60 \%$ & $44.58^{\text {* * }}$ & $70.14^{* *}$ & $45.25 \%$ & $48.94 * \cdots$ \\
\hline $\mathrm{N}$ & 765 & 770 & 787 & 769 & 771 \\
\hline
\end{tabular}

Notes: Coefficients are marginal effects coefficients computed following logistic regression estimation; standard errors are in parentheses. *** $<.01$, *p $<.05$. The data are from a random-sample national telephone survey of adults conducted for the Program on International Policy Attitudes, "Americans on Detention, Torture, and the War on Terrorism," July 9 to 15, 2004. 
Table 3. Predicting support for interrogation tactics, Part 3

\begin{tabular}{|c|c|c|c|c|c|}
\hline $\begin{array}{l}\text { Independent } \\
\text { Variables }\end{array}$ & $\begin{array}{l}\text { Electric } \\
\text { Shock }\end{array}$ & $\begin{array}{l}\text { Sexually } \\
\text { Humiliate }\end{array}$ & $\begin{array}{l}\text { Threaten with } \\
\text { Dogs }\end{array}$ & $\begin{array}{l}\text { Offer Positive } \\
\text { Incentive }\end{array}$ & $\begin{array}{c}\text { Remain in Physically Stressful } \\
\text { Position }\end{array}$ \\
\hline \multirow[t]{2}{*}{ Republican } & .039 & $.050 \#$ & $.219^{* * *}$ & .040 & $.157^{* * * x^{*}}$ \\
\hline & $(.031)$ & $(.028)$ & $(.047)$ & $(.025)$ & $(.047)$ \\
\hline \multirow[t]{2}{*}{ Democrat } & $-.056^{*}$ & $-.049 \%$ & -.044 & $.049 \%$ & $-.101^{*}$ \\
\hline & $(.028)$ & $(.025)$ & $(.046)$ & $(.024)$ & $(.045)$ \\
\hline \multirow[t]{2}{*}{ Female } & $-.043 \#$ & $-.063^{*}$ & $-.109 \%$ & .001 & -.026 \\
\hline & $(.025)$ & $(.022)$ & $(.038)$ & $(.023)$ & $(.039)$ \\
\hline \multirow[t]{2}{*}{ Education } & $-.025^{*}$ & -.004 & -.013 & $.032^{* * *}$ & .005 \\
\hline & $(.013)$ & $(.011)$ & $(.019)$ & $(.011)$ & $(.019)$ \\
\hline \multirow[t]{2}{*}{ Age } & -.001 & -.000 & $-.004 \%$ & .000 & $-.004^{*}$ \\
\hline & $(.001)$ & $(.001)$ & $(.001)$ & $(.001)$ & $(.001)$ \\
\hline \multirow{2}{*}{ White } & -.061 & -.048 & .013 & .057 & $-.113^{*}$ \\
\hline & $(.038)$ & $(.034)$ & $(.050)$ & $(.035)$ & $(.051)$ \\
\hline \multirow[t]{2}{*}{ Never married } & .042 & .024 & -.010 & -.012 & -.087 \\
\hline & $(.039)$ & $(.034)$ & $(.053)$ & $(.035)$ & $(.053)$ \\
\hline \multirow[t]{2}{*}{ Children $<18$} & .010 & .002 & -.011 & $-.059 \#$ & -.011 \\
\hline & $(.031)$ & $(.026)$ & $(.047)$ & $(.033)$ & $(.049)$ \\
\hline \multirow[t]{2}{*}{ South } & -.028 & .013 & .003 & -.018 & .013 \\
\hline & $(.024)$ & $(.022)$ & $(.039)$ & $(.024)$ & $(.040)$ \\
\hline \multirow[t]{2}{*}{ Place size $>$ urban } & .021 & .017 & $.089 \%$ & .013 & $.128 \%$ \\
\hline & $(.030)$ & $(.025)$ & $(.045)$ & $(.030)$ & $(.046)$ \\
\hline \multirow[t]{2}{*}{ Scenario 1} & $-.072^{2}$ & -.019 & $-.107^{*}$ & -.002 & -.158 些 \\
\hline & $(.026)$ & $(.024)$ & $(.046)$ & $(.030)$ & $(.047)$ \\
\hline \multirow[t]{2}{*}{ Scenario 2} & $-.051 \#$ & -.031 & $-.090 \#$ & -.008 & $-.122^{*}$ \\
\hline & $(.026)$ & $(.023)$ & $(.047)$ & $(.031)$ & $(.049)$ \\
\hline
\end{tabular}


Table 3. Continued

\begin{tabular}{|c|c|c|c|c|c|}
\hline $\begin{array}{l}\text { Independent } \\
\text { Variables }\end{array}$ & $\begin{array}{l}\text { Electric } \\
\text { Shock }\end{array}$ & $\begin{array}{l}\text { Sexually } \\
\text { Humiliate }\end{array}$ & $\begin{array}{c}\text { Threaten with } \\
\text { Dogs }\end{array}$ & $\begin{array}{l}\text { Offer Positive } \\
\text { Incentive }\end{array}$ & $\begin{array}{c}\text { Remain in Physically Stressful } \\
\text { Position }\end{array}$ \\
\hline Scenario 3 & $\begin{array}{r}-.053^{*} \\
(.026)\end{array}$ & $\begin{array}{c}-.040 \# \\
(.023)\end{array}$ & $\begin{array}{r}-.046 \\
(.049)\end{array}$ & $\begin{array}{r}-.020 \\
(.030)\end{array}$ & $\begin{array}{c}-.128^{*} \\
(.049)\end{array}$ \\
\hline Constant & $\begin{array}{l}.028 \\
(.735)\end{array}$ & $\begin{array}{c}-1.536 \# \\
(.852)\end{array}$ & $\begin{array}{l}.362 \\
(.550)\end{array}$ & $\begin{array}{l}.475 \\
(.781)\end{array}$ & $\begin{array}{l}.746 \\
(.531)\end{array}$ \\
\hline Log likelihood & -297.993 & -247.170 & -466.128 & -267.480 & -488.553 \\
\hline Pseudo R-square & .05 & .06 & .07 & .04 & .06 \\
\hline Chi square & $32.30 * *$ & $32.15^{* 2}$ & $74.47^{\text {米婇 }}$ & $24.25 \%$ & 65.28 * * * \\
\hline $\mathrm{N}$ & 771 & 770 & 767 & 769 & 766 \\
\hline
\end{tabular}

Notes: Coefficients are marginal effects coefficients computed following logistic regression estimation; standard errors are in parentheses. ${ }^{* *} \mathrm{p}<.01,{ }^{*} \mathrm{p}<.05$, \#p $<$ .10. The data are from a random-sample national telephone survey of adults conducted for the Program on International Policy Attitudes, "Americans on Detention, Torture, and the War on Terrorism," July 9 to 15, 2004. 
electric shock. However, given that few respondents supported this technique, it is perhaps not surprising that partisan differences are minimal. Republican attitudes about offering positive incentives were not statistically different from those of non-Republicans. Meanwhile, Democrats tended to be less likely to support many of the harsh techniques, including electric shock and sexual humiliation, and more likely to be supportive of using positive incentives. However, in several cases, Democrats did not hold significantly different attitudes from nonDemocrats. Analysis of the data suggests that this is due in part to the fact that Independents (part of the reference group) tended to have attitudes more in line with Democrats.

As we expected, exposure to the four scenarios (the contextual frames) tended to influence attitudes. Relative to respondents who were exposed to Scenario 4, the one in which the potential for gaining information to prevent a terrorist attack was greatest, respondents who were exposed to Scenarios 1, 2, or 3 were somewhat less likely to support the use of harsh interrogation techniques in most cases. This was especially true of respondents exposed to Scenario 1, which was the scenario where valuable information was least likely to be obtained through interrogation. Attitudes about some techniques, such as forcing a detainee to be naked, do not appear to have been significantly influenced by exposure to the scenarios. Overall, contextual framing plays an important role in predicting attitudes about interrogation techniques - those exposed to contextual frames that suggested a high probability of obtaining information that could prevent a terrorist attack were more likely to support harsh interrogation techniques.

Most importantly, gender tends to be a strong predictor of support for various interrogation techniques. In fact, the results for gender match those from the cross-tabulations fairly closely. Women were more likely to oppose the use of harsh techniques in all but two cases withholding food or water and forcing the detainee to maintain a physically stressful position. In addition, the attitudes of women on offering positive incentives were statistically no different from those of men. We suspect that there is no gender gap for offering positive incentives because respondents overwhelmingly supported this technique. In the cases of withholding food or water and maintaining a physically stressful position, we believe that there is no gender difference because, relative to the other harsh techniques, all respondents were more likely to support these measures. This suggests that these two techniques tended to be viewed as less extreme, and thus perhaps not torture, by most respondents. 


\section{RELATIVE AND SUBSTANTIVE INFLUENCE OF GENDER AND CONTEXT}

Finally, because the coefficients presented in Tables $1-3$ are marginal effect coefficients, we can compare the relative predictive influence of gender and the contextual frame variables in our models. The size of the coefficients for the gender, contextual frames, and partisanship variables tells an interesting story. Overall, being Republican is more important than any other factor in predicting attitudes about most interrogation techniques - in seven models the coefficient for Republican is the largest, and in five additional models this coefficient is the second largest.

Meanwhile, gender is clearly a strong predictor as well, but the coefficient is the largest in only three models. It is interesting to note that the three models in which gender was most important were those predicting support for forcing a detainee to go naked, sexually humiliating a detainee, and holding a detainee's head under water. In part, it appears that the gender gap was greatest on techniques in which a detainee would be made to feel the most personally vulnerable. Also note that the variables for exposure to scenarios were often the second most important predictors of attitudes. This finding suggests that, even when controlling for a variety of respondent characteristics, support for harsh interrogation techniques can be significantly altered depending on the context in which the technique is employed.

The variables capturing the contextual frames were the most important predictor variables in four of the models and the second most important predictors in five of the models, indicating that contextual framing of an interrogation situation can, on average, be as important in predicting attitudes as partisanship or gender. This is a highly significant finding considering that this is the one variable in the model that can be easily modified.

The substantive import of gender, context, and partisanship can be evaluated by examining predicted probabilities for these variables. For example, in the model predicting support for kicking or punching a detainee, being female or Democrat decreases the likelihood of favoring this technique by $6 \%$ and being Republican increases the likelihood of favoring this technique by almost $6 \%$, while being exposed to any contextual frame other than Scenario 4 decreases the likelihood of favoring this technique by over $6 \%$. In the case of forcing a detainee to go naked, being female decreases the likelihood of favoring this 
technique by $14 \%$, being Democrat decreases the likelihood of favoring this technique by $10 \%$, and being Republican increases the likelihood of favoring this technique by almost $11 \%$, while being exposed to any contextual frame other than Scenario 4 decreases the likelihood of favoring this technique by no more than $4 \%$. These findings indicate that the substantive impact of gender on attitudes may have been greatest on techniques of a sexual nature, while contextual framing and partisanship may have had the greatest substantive impact on techniques directly involving violence.

\section{ADDITIONAL ANALYSIS: INTERACTIONS}

Our analysis has answered some questions but also raised interesting possibilities. For example, because contextual frames can increase support for interrogation techniques, can context increase support among women, who tend to be less supportive of harsh techniques? Likewise, while women are less supportive and Republicans tend to be more supportive of harsh techniques, can the influence of gender on attitudes be conditioned by partisanship? To answer these questions we subdivided the data set and estimated separate models for men and women. This subdivision of the data allowed us to test for interactions between key variables without the multicollinearity problems created by including multiple interaction variables in the same model.

First, we created a subset of data to examine the effect of context. We estimated the original models using only men from the original sample in one model, and in the second model we used only women. The key variable of interest here was the potentially different effect of contextual frames for men and women. Thus, columns one and two in Table 4 display the coefficients for exposure to Scenario 4 as estimated with the gender subsets. For example, on the question of supporting a technique of threatening a detainee's family, the coefficients for Scenario 4 under the male and female columns are positive and statistically significant. This means that both men and women who were exposed to Scenario 4 were more likely to support the use of this technique. More importantly, the coefficient for Scenario 4 is larger in the model only including women than it is in the model only including men. This indicates that exposure to the scenario increased female support for this technique slightly more than it did for men. The same pattern is evident for 
Table 4. Interactions: Conditional effect of context (Scenario 4) and Republican on gender

\begin{tabular}{|c|c|c|c|c|}
\hline & \multicolumn{2}{|c|}{ Contextual Frame } & \multicolumn{2}{|c|}{ Republican } \\
\hline & Males & Females & Males & Females \\
\hline Threaten to harm family & $.681 *$ & $.965^{*}$ & $.832 * *$ & .173 \\
\hline Punch or kick & .567 & $.814 \#$ & .382 & $.855 \#$ \\
\hline Deprive of sleep & $.664 *$ & $.796^{*}$ & $.954^{* * *}$ & $1.262 * ; *$ \\
\hline Withhold food/water & $.666^{*}$ & $.714^{*}$ & $.578 *$ & $.912^{* * *}$ \\
\hline Threaten with dogs & .370 & $.706^{*}$ & $.957^{* * *}$ & $928^{* * * * 2}$ \\
\hline Remain in physically stressful position & $.640 *$ & $.689 \%$ & .982 皮次 & .162 \\
\hline Bombard with noise & $.758 *$ & $.616^{*}$ & $1.180^{\text {米的 }}$ & $.893^{\text {;*⿻一𠃋 }}$ \\
\hline Hold head under water & $.643 \#$ & .614 & $.554 \#$ & .763 \\
\hline Threaten to shoot & $.638^{*}$ & $.587 \#$ & $910 * *$ & .107 \\
\hline Electric shock & $.903 *$ & .577 & $.663 *$ & -.157 \\
\hline Hood on head & $.680 *$ & $.416^{*}$ & $.829^{* * *}$ & $.572 *$ \\
\hline Expose to extreme heat or cold & .404 & .377 & $.987^{* * *}$ & $.623^{*}$ \\
\hline Sexually humiliate & .391 & .222 & .435 & .835 \\
\hline Force naked & 390 & .141 & .351 & $1.001^{*}$ \\
\hline Offer position incentive & .044 & .023 & 698 & .275 \\
\hline
\end{tabular}

Notes: Coefficients in columns one and two are logistic regression coefficients for Scenario 4 within gender subsets of the data (e.g., females only). Coefficients in columns three and four are logistic regression coefficients for Republican within gender subsets of the data. All variables from original model included (with Scenario 1 as the reference group). Sig. p. $<.01^{* * *} ; .05^{*} ; .10 \#$.

attitudes about several other techniques, but when it came to attitudes about some of the harshest measures, such as electric shock, women either were no more influenced than men by exposure to the scenario or were not influenced by the scenario at all. We interpret these findings to mean that women, who tended to be less supportive of most interrogation techniques, were convinced to support some techniques that either cause little direct pain or do not make a detainee very vulnerable, but context does not shape female attitudes about the most extreme techniques.

Columns three and four in Table 4 display only the coefficient for Republican in our separate models for men and women. This analysis demonstrates how partisanship conditions the effects of gender on support for various interrogation techniques. Overall, the results suggest that being Republican increases support for most techniques among both men (11 techniques) and women ( 8 techniques), but the effect is greater for men, who are already predisposed to support most techniques. The results also suggest that for about half the techniques (7), Republican women provided no more or less support than did women 
who were Democrats or Independents. Thus, although partisanship clearly conditions women's support for torture, and to a greater extent than for men, on some extreme techniques, such as electric shock, sexual humiliation, or threatening to shoot, partisan orientation toward the Republican Party did not increase female support.

In sum, both contextual frames and partisanship condition the relationship between gender and support for torture. Exposure to contextual frames can increase support among women as can being Republican. However, for some of the most extreme techniques, such as electric shock, women tended to be opposed, regardless of contextual frames or partisanship. These findings are consistent with Howell and Day's (2000) findings, and strongly suggest that researchers should explore how the influence of gender on attitudes is mediated by other factors. $^{7}$

\section{CONCLUSIONS}

The threat of terrorism faced by the United Stated has clearly changed the way that Americans think about politics and foreign policy, and may have changed attitudes about the treatment of America's perceived enemies. At the same time, revelations about American interrogation techniques in the war on terror have forced a national dialogue on human rights. In an effort to better understand attitudes toward torture, we outline a theoretical perspective as to why gender and contextual frames are likely to shape attitudes about torture. We then analyze data from a unique 2004 survey of American adults to explore the influence of gender and contextual frames on support for a variety of interrogation techniques in the war on terror. Our extended analysis leads us to draw several important conclusions.

First, our results suggest that gender and contextual frames shape support for harsh interrogation techniques. Our results appear to support the contention that differences in the socialization of males and females results in different attitudes about torture - women are less likely than men to support most methods of interrogation in our analysis. However, not all men support harsh techniques and not all women oppose harsh

7. We also tested interactions between gender and having children, education, age, and living in an urban area. None of these interactions was statistically significant in more than one or two models. Given that these results conflict with previous research (Howell and Day 2000), we are hesitant to draw broad conclusions based on null findings. 
techniques. We infer that this suggests a less than complete biological cause for gender differences in attitudes, or at least a combination of socialization and biology. Furthermore, our analysis demonstrates that the influence of gender on attitudes is conditioned by other factors, such as partisanship, which tends to support the socialization argument.

To test the effect of contextual frames, survey respondents in our sample were randomly exposed to four experimental conditions. Each condition varied the context in which interrogation techniques would be employed. In one, there was strong likelihood that information would be obtained that could prevent a terrorist attack. The results of our analysis do suggest that context influences support for torture - those respondents exposed to the context in which information could be gained to prevent a terrorist attack were more likely to support most interrogation techniques.

Second, the relative influence of predictors in the models suggests that being Republican is the single most important predictor of attitudes toward torture. However, gender and contextual frames are sometimes more important and often the second most important variables. Given that gender and partisanship are not characteristics that are easily changed, the substantive import of being able to change attitudes according to the context in which an interrogation is framed makes contextual frames perhaps the most substantively important factor in predicting attitudes about torture. Indeed, the Bush administration appears to be acutely aware of this fact, frequently placing the discussion of interrogation techniques within a context that implies that attacks will be averted and lives saved.

Third, there is some evidence that the effect of gender on support for interrogation techniques is conditioned by context. Women, who tended to be less supportive of most techniques, were more supportive of some techniques if they were exposed to an interrogation context in which information obtained might prevent a terrorist attack. However, female support for techniques that severely compromised a detainee's sense of vulnerability, such as sexual humiliation or forcing a detainee to go naked, were not affected by the context of the interrogation. Meanwhile, men, who were more supportive of interrogation techniques overall, were somewhat less influenced by the context in which interrogation occurred than were women, but context did shape men's attitudes as well.

Fourth, the influence of gender on attitudes was conditioned by partisanship. We conducted separate analyses of Republicans and nonRepublicans and discovered that a gender difference tended to be greater and more systematic for non-Republicans. In other words, across most 
interrogation techniques, the attitudes of Republican women are similar to those of Republican men, while non-Republican women tended to be less supportive of all techniques than were non-Republican men. Thus, our analysis suggests that for women who identify as Republican, this identification is more likely to shape attitudes about torture than does being a woman.

Finally, although our analysis provides an important contribution to the literature in identifying gendered differences in attitudes, and the effect of contextual frames, it also provides important insights for understanding public attitudes about torture. As political elites and citizens continue to debate the validity of a variety of questionable methods for defending against terrorist attacks, our analysis makes it clear that attitudes are malleable and should not be considered fixed in time, place, or even a single characteristic of an observer.

\section{REFERENCES}

Barkan, Steven E., and Steven F. Cohn. 2005. "Why Whites Favor Spending More Money to Fight Crime: The Role of Racial Prejudice." Social Problems 52 (2): 300-314.

Bjereld, Ulf. 2001. "Children and the Gender Gap in Foreign Policy Issues." Gender and Society 15 (2): 303-16.

Brody, Elaine M. 1990. Women in the Middle: The Parent Care Years. New York: Springer.

Conover, Pamela Johnston, and Virginia Sapiro. 1993. "Gender, Feminist Consciousness and War." American Journal of Political Science 37 (4): 1079-99.

Cullen, Francis T., Bonnie S. Fisher, and Brandon K. Applegate. 2000. "Public Opinion about Punishment and Corrections." Crime and Justice 27 (1): 1-79.

Davis, Darren W., and Brian D. Silver. 2004. "Civil Liberties vs. Security: Public Opinion in the Context of the Terrorist Attacks on America." American Journal of Political Science 48 (1): $28-46$.

Eichenberg, Richard. C. 2003. "Gender Differences in Public Attitudes toward the Use of Force by the United States, 1990-2003.” International Security 28 (1): 110-41.

Fischhoff, Baruch, Roxana M. Gonzalez, Deborah A. Small, and Jennifer S. Lerner. 2003. "Judged Terror Risk and Proximity to the World Trade Center." Journal of Risk and Uncertainty 26 (2-3): 137-51.

Gilligan, Carol. 1982. In a Different Voice: Psychological Theory and Women's Development. Cambridge, MA: Harvard University Press.

Greer, Edward. 2004. “We Don't Torture People in America: Coercive Interrogation in the Global Village." New Political Science 26 (3): 371-87.

Haghighi, Bahram, and Alma Lopez. 1998. "Gender and Perception of Prisons and Prisoners." Journal of Criminal Justice 26 (6): 453-64.

Haider-Markel, Donald P., Mark Joslyn, and Mohammad Tarek Al-Baghal. 2006. "Can We Frame the Terrorist Threat? Issue Frames, the Perception of Threat, and Opinions on Counter-Terrorism Policies." Terrorism and Political Violence 18 (4): 545-59.

Hooks, Gregory, and Clayton Mosher. 2005. "Outrages Against Personal Dignity: Rationalizing Abuse and Torture in the War on Terror." Social Forces 83 (4): 1627-45.

Hooyman, Nancy R., and Judith Gonyea. 1995. Feminist Perspectives on Family Care: Policies for Gender Justice. Thousand Oaks, CA: Sage. 
Howell, Susan E., and Christine L. Day. 2000. "Complexities of the Gender Gap." The Journal of Politics 62 (3): 858-74.

Huckfeldt, Robert, Jeffrey Levine, William Morgan, and John Sprague. 1999. “Accessibility and the Political Utility of Partisan and Ideological Orientations." American Journal of Political Science 43 (3): 888-911.

Huddy, Leonie, Stanley Feldman, Theresa Capelos, and Colin Provost. 2002. "The Consequences of Terrorism: Disentangling the Effects of Personal and National Threat." Political Psychology 23 (3): 485-507.

Huddy, Leonie, Stanley Feldman, Charles Taber, and Gallya Lahav. 2005. "Threat, Anxiety, and Support of Antiterrorism Policies." American Journal of Political Science 49 (3): 593-608.

Hurwitz, Jon, and Shannon Smithey. 1998. "Gender Differences on Crime and Punishment.” Political Research Quarterly 51 (1): 89-115.

Iyengar, Shanto. 1989. "How Citizens Think About National Issues: A Matter of Responsibility." American Journal of Political Science 33 (4): 878-900.

Iyengar, Shanto. 1990. "Framing Responsibility for Political Issues: The Case of Poverty." Political Behavior 12 (1): 19-40.

Jacobson, Gary C. 2007. A Divider, Not a Uniter: George W. Bush and the American People. New York: Pearson Longman.

Kaufmann, Karen M., and John R. Petrocik. 1999. “The Changing Politics of American Men: Understanding the Sources of the Gender Gap." American Journal of Political Science 43 (3): 864-87.

Kull, Steven. 2006. American and International Opinion on the Rights of Terrorism Suspects. College Park, MD: The Program on International Policy Attitudes.

Lerner, Jennifer S., Roxana M. Gonzalez, Deborah A. Small, and Baruch Fischhoff. 2003. "Effects of Fear and Anger on Perceived Risks of Terrorism: A National Field Experiment." Psychological Science 14 (2): 144-50.

McCoy, Alfred. 2006. A Question of Torture: CIA Interrogation, from the Cold War to the War on Terror. New York: Metropolitan Books.

McCue, Clifford P., and J. David Gopoian. 2000. "Dispositional Empathy and the Political Gender Gap." Women \& Politics 21 (2): 1-20.

Nincic, Miroslav, and Donna J. Nincic. 2002. "Race, Gender, and War." Journal of Peace Research 39 (5): 547-68.

Ortega, Suzanne T., and Jessie L. Myles. 1987. "Race and Gender Effects on Fear of Crime: An Interactive Model with Age." Criminology 25 (1): 133-52.

Pew Research Center, The. 2007. Trends in Political Values and Core Attitudes: 1987-2007, March 22, 2007. Washington, DC: The Pew Research Center for People and the Press.

Posner, Richard. 2004. "Torture, Terrorism and Interrogation," In Torture: A Collection, ed. Sanford Levinson. New York: Oxford University Press, 291-98.

Rohter, Ira S. 1969. "Social and Psychological Determinants of Radical Rightism." In The American Right Wing: Readings in Political Behavior, ed. Robert A. Schoenberger. New York: Holt, Rinehart and Winston. 232-58.

Shapiro, Robert Y., and Harpreet Mahajan. 1986. "Gender Differences in Policy Preferences: A Summary of Trends from the 1960s to the 1980s." Public Opinion Quarterly 50 (1): 42-61.

Singer, Tania, Ben Seymour, John P. O’Doherty Klaas E. Stephan, Raymond J. Dolan, and Chris D. Frith. 2006. "Empathic Neural Responses Are Modulated by the Perceived Fairness of Others." Nature 439 (January): 466-69.

Smith, Tom W. 1984. "The Polls: Gender and Attitudes Toward Violence.” Public Opinion Quarterly 50 (1): 42-61.

Stanko, Elizabeth. 1990. Everyday Violence. London: Pandora. 
Unnever, James D., Francis T. Cullen, and Bonnie S. Fisher. 2007. “'A Liberal Is Someone Who Has Not Been Mugged': Criminal Victimization and Political Beliefs." Justice Quarterly 24 (2): 309-34.

Warr, Mark. 1995. "Poll Trends: Public Opinion on Crime and Punishment." Public Opinion Quarterly 59 (2): 296-310.

Wilcox, Clyde, Lara Hewitt, and Dee Allsop. 1996. "The Gender Gap in Attitudes toward the Gulf War: A Cross-National Perspective." Journal of Peace Research 33 (1): 67-82.

Worden, Alissa Pollitz. 1993. "The Attitudes of Women and Men in Policing: Testing Conventional and Contemporary Wisdom." Criminology 31 (2): 203-41.

\section{APPENDIX}

Specific Interrogation Techniques and Gender and Party Differences in Support

1. Not allowing the detainee to sleep

Oppose

Gender Party

Favor

\begin{tabular}{cccc}
\multicolumn{2}{c}{ Gender } & \multicolumn{2}{c}{ Party } \\
Male & Female & Democrat & Republcan \\
\hline $35.4 \%$ & $46.4 \%$ & $50.0 \%$ & $22.4 \%$ \\
$64.7 \%$ & $53.7 \%$ & $50.0 \%$ & $77.6 \%$
\end{tabular}

2. Keeping a hood over the detainee's head for long periods of time

\begin{tabular}{lcrrr} 
& \multicolumn{2}{c}{ Gender } & \multicolumn{2}{c}{ Party } \\
& Male & Female & Democrat & Republcan \\
\cline { 2 - 5 } Oppose & $42.7 \%$ & $55.1 \%$ & $59.1 \%$ & $40.9 \%$ \\
Favor & $57.3 \%$ & $44.9 \%$ & $32.8 \%$ & $67.2 \%$
\end{tabular}

3. Bombarding the detainee with loud noise for long periods of time

Gender Party

Male Female Democrat Republcan

Oppose

\begin{tabular}{llll}
\hline $43.9 \%$ & $58.6 \%$ & $58.9 \%$ & $33.5 \%$ \\
$56.1 \%$ & $41.5 \%$ & $41.1 \%$ & $66.5 \%$
\end{tabular}

4. Threatening to shoot the detainee

\begin{tabular}{lcccc} 
& \multicolumn{2}{c}{ Gender } & \multicolumn{2}{c}{ Party } \\
& Male & Female & Democrat & Republcan \\
\cline { 2 - 5 } Oppose & $60.8 \%$ & $73.0 \%$ & $73.3 \%$ & $55.8 \%$ \\
Favor & $39.2 \%$ & $27.0 \%$ & $26.7 \%$ & $44.2 \%$
\end{tabular}

5. Exposing the detainee to extreme heat or cold

Gender Party

Oppose

Male Female Democrat Republcan

Favor

\begin{tabular}{llll}
\hline $66.0 \%$ & $77.9 \%$ & $81.9 \%$ & $56.2 \%$ \\
$34.0 \%$ & $22.1 \%$ & $18.1 \%$ & $43.8 \%$
\end{tabular}

6. Withholding food and water

Oppose

Favor

Gender Party

Male Female Democrat Republcan

\begin{tabular}{llll}
\hline $62.9 \%$ & $68.1 \%$ & $71.9 \%$ & $53.7 \%$
\end{tabular}

$37.2 \% \quad 31.9 \% \quad 28.1 \% \quad 46.3 \%$


7. Punching or kicking the detainee

Oppose

Favor

\begin{tabular}{cccc}
\multicolumn{2}{c}{ Gender } & \multicolumn{2}{c}{ Party } \\
Male & Female & Democrat & Republcan \\
\hline $82.6 \%$ & $90.0 \%$ & $91.0 \%$ & $80.4 \%$ \\
$17.4 \%$ & $10.1 \%$ & $9.0 \%$ & $19.6 \%$
\end{tabular}

8. Making the detainee go naked

Oppose

Favor

Gender

Party

Male Female Democrat Republcan

9. Holding the detainee's head under water

\begin{tabular}{llll}
\hline $68.8 \%$ & $84.7 \%$ & $86.4 \%$ & $64.5 \%$ \\
$31.2 \%$ & $15.3 \%$ & $13.6 \%$ & $35.5 \%$
\end{tabular}

\begin{tabular}{lrrrr} 
& \multicolumn{2}{c}{ Gender } & \multicolumn{2}{c}{ Party } \\
& Male & Female & Democrat & Republcan \\
\cline { 2 - 5 } Oppose & $82.9 \%$ & $91.5 \%$ & $91.4 \%$ & $81.1 \%$ \\
Favor & $17.1 \%$ & $8.5 \%$ & $8.7 \%$ & $18.9 \%$
\end{tabular}

10. Threatening to harm the detainee's family members

\begin{tabular}{lcccc} 
& \multicolumn{2}{c}{ Gender } & \multicolumn{2}{c}{ Party } \\
& Male & Female & Democrat & Republcan \\
\cline { 2 - 5 } Oppose & $71.8 \%$ & $83.8 \%$ & $83.4 \%$ & $68.2 \%$ \\
Favor & $28.2 \%$ & $16.2 \%$ & $16.6 \%$ & $31.8 \%$
\end{tabular}

11. Applying electric shocks to the detainee

Oppose

Favor

Gender

Party

Male Female Democrat Republcan

\begin{tabular}{rrrr}
\hline $83.6 \%$ & $88.6 \%$ & $90.3 \%$ & $81.6 \%$ \\
$16.4 \%$ & $11.4 \%$ & $9.7 \%$ & $18.4 \%$
\end{tabular}

12. Sexually humiliating the detainee

\begin{tabular}{lrrrr} 
& \multicolumn{2}{c}{ Gender } & \multicolumn{2}{c}{ Party } \\
& Male & Female & Democrat & Republcan \\
\cline { 2 - 5 } Oppose & & & & \\
Favor & $14.4 \%$ & $93.5 \%$ & $93.8 \%$ & $83.6 \%$ \\
& & $6.5 \%$ & $6.2 \%$ & $16.4 \%$
\end{tabular}

13. Using threatening dogs to frighten detainees

Gender Party

Male Female Democrat Republcan

Oppose

\begin{tabular}{llll}
\hline $58.8 \%$ & $69.7 \%$ & $74.0 \%$ & $47.5 \%$
\end{tabular}

Favor

$41.2 \% \quad 30.3 \% \quad 26.0 \%$

$52.5 \%$

14. Offering detainees a positive incentive for giving information
Gender
Party

Oppose

Male Female Democrat Republcan

Favor

\begin{tabular}{rrrr}
\hline $11.1 \%$ & $13.1 \%$ & $10.5 \%$ & $9.8 \%$ \\
$88.9 \%$ & $86.9 \%$ & $89.6 \%$ & $90.2 \%$
\end{tabular}


15. Forcing detainees to remain in a physically stressful position for an extended period Gender Party Male Female Democrat Republcan

Oppose

\begin{tabular}{llll}
\hline $55.5 \%$ & $61.2 \%$ & $68.1 \%$ & $44.9 \%$ \\
$44.5 \%$ & $38.8 \%$ & $31.9 \%$ & $55.1 \%$
\end{tabular}

Note: All gender and party differences (Independent excluded) are statistically significant (Pearson chisquare test, p. $<.05)$, except on question 14 . 